\title{
ANALISIS PENETAPAN HARGA JUAL PADA PEMBIAYAAN MURABAHAH BERDASARKAN PERSPEKTIF ISLAM DI BMT UGT SIDOGIRI CAPEM PAJARAKAN (Studi Kasus Bank Syariah Mandiri KC Lumajang)
}

\author{
Hayatul Millah $^{1}$ Ayik Andriani ${ }^{2}$ \\ Universitas Islam Zainul Hasan Genggong Probolinggo
}

\begin{abstract}
ABSTRAK
Penelitian ini bertujuan untuk menentukan penetapan harga jual pada pembiayaan murabahah berdasarkan perspektif Islam di BMT UGT Sidogiri Capem Pajarakan. Penelitian ini menggunakan pendekatan kualitatif, yaitu penelitian yang tujuan utamanya adalah untuk memperoleh wawasan tentang topik tertentu. Teknik yang digunakan dalam penelitian kualitatif pada umumnya menggunakan metode wawancara, peneliti terjun langsung ke lapangan agar dapat menanyakan atau mewawancarai para staf BMT, agar data yang diperoleh akurat dan dapat di percaya. Hasil penelitian menunjukkan bahwa mekanisme penetapan harga yang digunakan di BMT UGT yaitu atas dasar negoisasi (tawar-menawar) yaitu dengan membentuk kesepakatan antara kedua belah pihak tanpa adanya unsur paksaan yang berpegangan dengan prinsip-prinsip syariah, penetapan harga akad murabahah di BMT UGT Capem Ketompen-Pajarakan berpatokan terhadap jumlah pengajuan pembiayaan dengan ketentuan margin antara $2 \%$ sd 2,5\%, kesesuaian penetapan harga jual pada pembiayaan murabahah di BMT UGT Capem Ketompen-Pajarakan Menurut tinjauan hukum perspektif Islam telah sesuai dengan tuntunan syariah, karena mengacu pada Fatwa DSN No. 04/DSN-MUI/IV/2000 tentang pembiayaan murabahah
\end{abstract}

\section{PENDAHULUAN}

Lembaga Keuangan Mikro Syariah (LKMS) adalah Lembaga keuangan yang mempunyai peran yang sangat besar bagi pertumbuhan ekonomi masyarakat industri modern. LKMS merupakan sebuah lembaga perekonomian mikro syariah yang bergerak di bidang menghimpun dan menyalurkan dana kepada masyarakat seperti penghimpunan 
dana (wadhiah, mudharabah) dan penyaluran dana (prinsip bagi hasil, jual beli dan ijarah) pada masyarakat (Kusmiyati dan Asmi Nur Siwi, 2007). Penyaluran dana dengan prinsip jual beli dilakukan dengan akad murabahah, salam, dan istishna. Sedangkan murabahah merupakan akad yang paling dominan yang digunakan dalam melakukan transaksi jual beli. Salah satu bentuk dari Lembaga Keuangan Mikro Syariah adalah Baitul Mal wa Tamwil (BMT).

Pembiayaan dengan akad murabahah merupakan pembiayaan yang sangat dominan dan banyak diminati oleh nasabah dalam bertransaksi, akad murabahah yaitu akad jual beli dimana penjual harus menyebutkan harga pembelian barang kepada pihak pembeli kemudian pihak penjual mensyaratkan atas laba dengan jumlah tertentu sehingga kedua belah pihak dapat membuat kesepakatan atas laba yang telah disyaratkan.

Pembiayaan dengan menggunakan akad murobahah juga menjadi produk yang mempunyai peminat yang paling banyak di BMT UGT Sidogiri, jumlah nasabah pembiayaan murabahah ini mengalami perkembangan yang pesat dari tahun ke tahun. Hal ini terbukti pada tahun 2019 jumlah nasabah pembiayaan murabahah mencapai sebesar 4.210 nasabah dibandingkan dari pembiayaan yang lain seperti: Musyarakah sebanyak 2500 nasabah, mudharabah, Qard, dan Istisna' berturut turut sebesar 2047, 884, 1121 nasabah.

Jumlah minat nasabah pembiayaan murabahah di BMT UGT Ketompen Padjarakan selalu meningkat setiap tahunnya. Peningkatan setiap tahunnya 13\% - 29\%. Seperti dari tahun 2017 terdapat 2.596 nasabah pada tahun 2018 meningkat menjadi 2.982 Nasabah atau terjadi kenaikan sebesar 13\% dari tahun sebelumnya, pada tahun 2019 meningkat menjadi 4.210 atau persentase sebesar $29 \%$.

Salah satu faktor yang berperan penting bagi BMT UGT Sidogiri dalam meningkatkan jumlah nasabah untuk melakukan pembiayaan adalah penetapan harga. Harga menjadi penting karna dapat menentukan ketertarikan nasabah terhadap suatu produk baik barang maupun jasa, apabila dalam hal penentuan harga suatu barang atau jasa mengalami kesalahan, maka akan mengakibatkan kerugian bagi pihak BMT. Penetapan harga jual pada pembiayaan murabahah merupakan unsur penting yang memiliki kaitan erat dengan keberhasilan BMT dalam meningkatkan keuntungan dan juga untuk mempertahankan serta menambah anggotanya yaitu dengan cara memberikan 
harga jual pembiayaan murabahah yang rendah dan tidak memberatkan terhadap anggota.

\section{LANDASAN TEORI}

\section{Penetapan Harga}

Harga adalah sejumlah uang yang dibayarkan atas barang dan jasa atau jumlah nilai yang konsumen tukarkan dalam rangka mendapatkan manfaaat dari memiliki atau menggunakan barang atau jasa (Philip Kotler, 2007). Harga juga merupakan salah satu penentu keberhasilan suatu perusahaan karena harga menentukan seberapa besar keuntungan yang akan diperoleh perusahaan dari penjuaalan produknya baik berupa barang maupun jasa. Menetapkan harga terlalu tinggi akan menyebabkan penjualan akan menurun, namun harga jika terlalu rendah akan mengurangi keuntungan yang dapat diperoleh organisasi perusahaan. konsep yang lain menunjukkan apabila harga sebuah barang yang di beli oleh konsumen dapat memberikan hasil yang memuaskan, maka dapat dikatakan bahwa penjualan total perusahaan akan berada pada tingkat yang memuaskan, diukur dalam nilai rupiah, sehingga dapat menciptakan pelanggan. Penetapan harga merupakan aspek yang sangat penting dalam kegiatan bisnis. Harga menjadi penting karna menentukan laku tidak lakunya suatu produk barang atau jasa tersebut. Jika dalam menentukan harga mengalami kesalahan, maka nantinya akan berakibat fatal dan merugikan perusahaan itu sendiri. Bagi perbankan konvensional harga adalah bunga, biaya administrasi, biaya komisi, biaya kirim, biaya sewa, dan biayar iuran. Sedangkan harga bagi perbankan yang menggunakan prinsip syariah adalah bagi hasil.

Penetapan harga dalam pembiayaan dilembaga keuangan syariah sekarang ini lazimnya mengunakan metode going rate pricing yaitu kebijakanapenentuan harga dengan menggunakan tingkat suku bunga pasar sebagai rujukan. Adapun alasannya karena lembaga keuangan syariah berkompetisi dengan bank konvensional. Disamping itu mereka juga berkeinginan untuk mendapatkan nasabah yang bersifat floating costumer.

\section{Murabahah}

Menurut PSAK 102 Akutansi Murabahah, menyatakan bahwa Murabahah akad jual beli barang dengan harga jual sebesarbiaya perolehan ditambah keuntungan yang di sepakati dan penjual harus mengungkapkan biaya perolehan barang tersebut kepada pembeli. Fatwa DSN NO.04/DSN-MUI/IV/2000 berisi pengertian murabahah, yaitu 
menjual suatu barang dengan menegaskan harga belinya kepada pembeli dan pembeli membayarnya dengan harga yang lebih sebagai laba. Sebagian produk penyaluran dana kepada masyarakat adalah berupa pembiayaan didasarkan pada akad jual beli (IKAPI, 2009). $B a$ 'i al-murabahah sebagaimana didefinisikan oleh ulama fiqh adalah jual beli barang pada harga asal dengan tambahan keuntungan yang disepakati.

Rukun murabahah adalah seperti rukun jual beli pada umum nya, yang menurut jumhur ulama' adalah : aqidain, adanya objek jual beli, sigat, harga yang disepakati.jika keempat hal tersebut ditemukan, maka jual beli dianggap memenuhi rukunnya. Sedangkan Syarat Bai' Murabahah yaitu :

a. Harga awal harus diketahui oleh kedua belah pihak ( penjual dan pembeli), dalam akad murabahah penjual wajib menyampaikan secara transparan harga beli pertama dari barang yangakan ia jual kepada pembeli. Sedangkan pembeli mempunyai hak untuk mengetahui harga beli barang. Persyaratan ini juga berlaku bagi jual beli yang sejenis, sepertri Al-isyrak, Al-tauliyah, dan Al-wadli'ah.

b. Besarnya keuntungan harus diketahui dan disepakati oleh kedua belah pihak. Penjual wajib menyampaikan keuntungan yang diinginkan dan pembeli mempunyai hak untuk mengetahui bahkan menyepakati keuntungan yang akan diperoleh oleh penjual. Jika salah satu dari pihak tidak sepakat terhadap keuntungan penjual, maka akad murabahah tidak terjadi.

c. Harga pokok dapat diketahui secara pasti satuannya. Seperti satu dirham, satu dinar, seratus kilogram gandum, satu kwintal beras dan lain-lain.sebab dalam murabahah, dan juga dalam jual beli manah lainnya yang dikehendaki adalah adanya transparansi antar harga pokok dan kemungkinan laba yang akan diperoleh. Jika barang yang akan ditransaksikan tidak diketahui satuannya, maka akan sulit menentukan keuntungan yang akan diperoleh.

d. Akad pertama dalam murabahah harus jelas. Jika pada pembelian pertama tidak dilakukan dengan cara yang jelas, maka transaksi murabahah dianggap batal.

Fatwa DSN-MUI No. 84 Tahun 2012 Tentang Metode Pengakuan Keuntungan $\mathrm{Al}$ Tamwil Bi Al-Murabahah (Pembiayaan Murabahah) di Lembaga Keuangan Syariah 
Fatwa DSN MUI No. 84 tahun 2012 tentang Metode Pengakuan Keuntungan Al-Tamwil Bi Al-Murabahah (Pembiayaan Murabahah) di Lembaga Keuangan Syariah.

1. Ketentuan Umum Dalam fatwa ini yang dimaksud dengan:

a. Metode proporsional (Tariqah Mubasyirah) adalah pengakuan keuntungan yang dilakukan secara proporsional atas jumlah piutang (harga jual, saman) yang berhasil ditagih dengan mengalikan persentase keuntungan terhadap jumlah piutang yang berhasil ditagih (al-asman al-muhasalah).

b. Metode Anuitas (Tariqah al-Hisab al-Tanazuliyyah/Tariqah alTanaqusiyyah) adalah pengakuan keuntungan yang dilakukan secara proporsional atas jumlah sisa harga pokok yang belum ditagih dengan mengalikan persentase keuntungan terhadap jumlah sisa harga pokok yang belum ditagih (al-asman al-mutabaqqiyah).

c. Murabahah adalah akad jual-beli dengan menegaskan harga belinya kepada pembeli dan pembeli membayarnya dengan harga yang lebih sebagai keuntungan.

d. At-Tamwil bi al-Murabahah (Pembiayaan Murabahah) adalah murabahah di Lembaga Keuangan Syariah (LKS) dengan cara LKS membelikan barang sesuai dengan pesanan nasabah, kemudian LKS menjualnya kepada nasabah setelah barang menjadi milik LKS dengan pembayaran secara angsuran.

e. Harga Jual (saman) adalah harga pokok ditambah keuntungan.

f. Al-Maslahah (aslah) adalah suatu keadaan yang dianggap paling banyak mendatangkan manfaat bagi pertumbuhan Lembaga Keuangan Syariah yang sehat.

2. Ketentuan Hukum

Metode pengakuan keuntungan Murabahah dan Pembiayaan Murabahah boleh dilakukan secara proporsional dan secara anuitas dengan mengikuti ketentuan-ketentuan dalam fatwa ini.

3. Ketentuan Khusus

a. Pengakuan keuntungan murabahah dalam bisnis yang dilakukan oleh para pedagang (al-tujjar), yaitu secara proporsional boleh dilakukan selama sesuai dengan 'urf (kebiasaan) yang berlaku di kalangan para pedagang; 
b. Pengakuan keuntungan al-Tamwil bi al-Murabahah dalam bisnis yang dilakukan oleh Lembaga Keuangan Syariah (LKS) boleh dilakukan secara Proporsional dan secara Anuitas selama sesuai dengan 'urf (kebiasaan) yang berlaku di kalangan LKS

c. Pemilihan metode pengakuan keuntungan al-Tamwil bi al-Murabahah pada LKS harus memperhatikan mas\}lahah LKS bagi pertumbuhan LKS yang sehat.

d. Metode pengakuan keuntungan al-Tamwil bi al-Murabahah yang aslah dalam masa pertumbuhan LKS adalah metode Anuitas.

e. Apabila LKS menggunakan metode pengakuan keuntungan al-Tamwil bi alMurabahah secara anuitas, porsi keuntungan harus ada selama jangka waktu angsuran; keuntungan al-Tamwil bi al-Murabahah (pembiayaan murabahah) tidak boleh diakui seluruhnya sebelum pengembalian piutang pembiayaan murabahah berakhir atau lunas dibayar.

\section{METODOLOGI PENELITIAN}

Penelitian ini menggunakan pendekatan kualitatif, yaitu penelitian yang tujuan utamanya adalah untuk memperoleh wawasan tentang topik tertentu. Teknik yang digunakan dalam penelitian kualitatif pada umumnya menggunakan metode wawancara, peneliti terjun langsung ke lapangan agar dapat menanyakan atau mewawancarai para staf BMT, agar peneliti mendapatkan data yang akurat dan dapat di percaya. observasi dan dokumentasi, metode dokumentasi di lakukan oleh peneliti bertujuan agar peneliti memiliki bukti yang nyata untuk di jabarkan serta sebagai penegas keaslian dari penelitian ini.

\section{HASIL DAN PEMBAHASAN}

\section{Mekanisme Penetapan Harga Jual pada Pembiayaan Murabahah di BMT UGT Sidogiri Capem Ketompen Pajarakan.}

Mekanisme penetapan harga jual pembiayaan murabahah di BMT UGT Capem Ketompen-Pajarakan adalah dengan mengedepankan proses Negoisasi (tawar-menawar) yaitu dengan membentuk kesepakatan antara kedua belah pihak tanpa adanya unsur paksaan. 
Tawar menawar atau negoisasi yang dilakukan didasari atas prinsip-prinsip syariah seperti halnya:

a. Prinsip saling ridho

Yang dimaksud prinsip saling ridlho adalah tidak adanya keterpaksaan dari salah satu pihak baik BMT maupun calon anggota didalam melakukan kesepakatan mengenai margin yang ditetapkan.

b. Prinsip keadilan.

Yang dimaksud dengan Prinsip keadilan adalah dalam hal penentuan harga jual pada pembiayaan murabahah yang dilakukan oleh pihak BMT UGT dan anggota tidak adanya pihak yg dirugikan dan diberatkan.

Penentuan harga jual BMT UGT Sidogiri capem Ketompen Pajarakan didasarkan beberapa pertimbangan seperti:

a. Jangka waktu (tenor)

Jangka waktu adalah periode waktu dilakukannya pengembalian pembiayaan. Di BMT UGT Sidogiri jangka waktu pembiayaan adalah 4 bulan sampai dengan 36 bulan. Apabila jangka waktu pembiayaan pendek maka penetapan margin yang ditawarkan akan lebih kecil dan apabila jangka waktu panjang maka margin akan lebih besar.

b. Penggunaan dana dan kondisi anggotanya

Pengunaan dana dan kondisi anggota adalah hal yang menjadi mempertimbangan BMT UGT Sidogiri dalam hal memberikan keputusan persetujuan harga jual dan jangka waktu pembiayaan serta kemampuan anggota untuk mengangsur setiap bulan. Adapun prinsip-prinsip penilaian yang dijadikan pedoman untuk menilai kelayakan anggota mendapatkan pembiayaan murabahah dilakukan dengan analisis 5C, yaitu character (riwayat pembiayaan sebelumnya), capacity (kapasitas), capital, condition, dan collateral (jaminan).

Harga jual pada pembiayaan murabahah merupakan harga pokok yang ditambah dengan keuntungan yang telah disepakati antara penjual dan pembeli. Akibat dari harga jual murabahah yang pembayarannya dilakukan secara tangguh adalah timbulnya hutang nasabah yang dilukakan dengan cara pembayaran angsuran.

Pembayaran angsuran adalah pembayaran yang tidak diterima sekaligus (tidak langsung tunai), pembayarannya bisa dilakukan dengan pembayaran musiman atau 
bulanan. Dalam pembiayaan angsuran pada pembiayaan murabahah terkadang lebih tinggi dari harga tunai.

Mengapresel harga terhadap anggota sesuai dengan harga taksasi. Dimana pada dasarnya perhitungan margin ( keuntungan) pembiayaan murabahah menggunakan aqad murabahah pembayaran dengan metode flat (metode penetapan harga rata-rata). Dimana pihak BMT UGT menjual barang kepada anggota (pemesan) dengan harga beli ditambah keuntungannya (margin) yang mana pihak BMT UGT harus memberi tahu secara jujur harga pokok barang kepada anggota, sehingga anggota membayar harga barang yang telah disepakati antara kedua belah pihak.

Besaran presentase margin murabahah di tentukan sesuai dengan besar kecilnya jumlah pembiayaan yang di ajukan oleh anggota. Di BMT UGT Sidogiri jumlah pembiayaan tertinggi sesuai dengan kebijakan kantor pusat hanya sebesar 50.000.000. besaran presentase pada produk murabahah yang ada di BMT UGT Cabang KetompenPajarakan juga di sesuaikan dengan besar jumlah pembiayaan yang di ajukan oleh anggota di setiap bulannya. Contohnya pembiayaan dengan jumlah 500.000-5.000.000 persentase marginnya sebesar 2,5\%, pembiayaaan dengan jumlah 6.000.000-10.000.000 persentase marginnya sebesar 2,3\%, dan pembiayaan dengan jumlah 11.000.00050.000 .000 persentase marginnya sebesar 2\%. Akan tetapi pada penentuan harga pembiayaan di BMT UGT dilakukan atas dasar negoisasi yang mana persentase margin dapat ditawar oleh anggota. Sehingga persentase margin bisa kurang dari patok an persentase yang sudah ditetapkan oleh pihak BMT UGT.

Penentuan margin memang ditentukan dari pusat tetapi perlu digaris bawahi bahwa persentase margin tersebut tergantung pada kebijakan komite atau kepala Capem. Karena yang terpenting bagi pusat tidak melebihi dari batas maksimal dan tidak mengurangi dari batas minimal, namun menurut AO di BMT UGT bahwa melebihi tidak masalah asalkan pihak anggota ihklas dan tidak merasa terbebani.

Adapun prosedur yang dilakukan oleh pihak BMT dalam setelah AO selesai melakukan survey terhadap calon yang mengajukan pinjaman adalah penandatanganngan akta perjanjian pembiayaan dengan pengikatan agunan yang dilakukan oleh komite dan calon anggota dihadapan notaris sebagai syarat pencairan dana yang diajukan. Agunan yang disyaratkan oleh BMT sebagai jaminan dapat berupa komoditas atau aset lain 
dimaksudkan untuk meminimalisir terjadinya risiko kredit atau kegagalan anggota dalam membayar angsuran.

Pembiayaan yang diajukan peminjam dapat dicairkan dalam jangka waktu paling cepat sekitar 3 hari dengan catatan jika sang peminjam pernah mengajukan pembiayaan ke BMT sebelumnya maka dapat dikatakan anggota lama, sedangkan jangka waktu cair paling lama sekitar 7 hari atau lebih dengan catatan jika sang peminjam tidak pernah mengajukan pembiayaan sama sekali terhadap BMT atau bisa dikatakan anggota baru. Proses analisis jaminan biasanya BMT UGT Sidogiri Capem Ketompen Pajarakan melihat dari beberapa aspek yaitu seperti : kualitas Aset atau komoditas, harga pasar aset, modal calon anggota yang dimiliki sekarang dan dilihat juga dari usaha-usaha yang mereka miliki. Sedangkan untuk Jenis-jenis aset yang dapat dijadikan jaminan seperti: tanah, bangunan, motor, mobil, BPKB, dan lain-lain.

\section{Penetapan Harga Jual pada Pembiayaan Murabahah di BMT UGT Capem Pajarakan}

Penetapan harga merupakan aspek yang sangat penting bagi BMT UGT Capem Ketompen-Pajarakan dalam kegiatan pemasaran. Harga menjadi penting karna menentukan laku tidak lakunya suatu produk barang atau jasa tersebut. Jika dalam menentukan harga mengalami kesalahan, maka nantinya akan berakibat fatal dan merugikan BMT UGT sendiri .

Adapun rumus sederhana yang di gunakan pihak BMT untuk mengetahui total angsuran, pokokpembiayaan dan margin keuntungan yaitu sebagai berikut:

Jumlah angsuran $=$ pokok + margin

Pokok $=$ jumlah pembiayaan $:$ jangka waktu

Margin keuntungan = jumlah pembiayaan $\mathrm{x}$ presentase margin

Margin keuntungan yang ditetapkan oleh BMT UGT Sidogiri melihat margin keuntungan yang telah ditetapkan oleh BMT lainnya sebagai pesaing langsung terdekat. Karena pada dasarnya penetapan harga jual pembiayaan murabahah dipengaruhi oleh besar kecilnya pinjaman pembiayaan, semakin besar jumlah pinjaman yang disepakati oleh anggota maka semakin kecil juga margin yang didapat oleh pihak BMT sedangkan apabila kecil jumlah pinjaman yang disepakati oleh anggota maka semakin besar margin yang didapat oleh pihak BMT. 


\section{Kesesuaian Penetapan Harga Jual pada Pembiayaan Murabahah di BMT UGT Sidogiri Capem Ketompen Pajarakan Menurut Perspektif Islam}

Sebagaimana yang telah diketahui, pada dasarnya akad murabahah merupakan jual beli dengan kesepakatan pemberian keuntungan bagi sipenjual dengan memperhatikan dan memperhitungkan modal awal si penjual. Adapun unsur utama jual beli murabahah adalah dengan adanya kesepakatan terhadap keuntungan. Keuntungan itu ditetapkan dan disepakati dengan memperhatikan modal sipenjual. Sedangkan keterbukaan dan kejujuran menjadi syarat utama terjadinya murabahah, sehingga yang menjadi karakteristik dari akad murabahah adalah penjual harus memberi tahu pembeli tentang harga pembelian barang dan menyatakan jumlah keuntungan yang ditambahkan pada harga beli barang tersebut. Jadi, pada dasarnya perhitungan margin (keuntungan) pada pembiayaan murabahah dengan menggunakan aqad murabahah dengan metode pembayaran flat (rata-rata) yang dilakukan di BMT UGT Sidogiri Capem KetompenPajarakan telah sesuai dengan tuntunan syariah karena sesuai dengan Fatwa DSN No. 04/DSN-MUI/IV/2000 tentang pembiayaan murabahah yang menyatakan bahwa bank ketika menjual barang kepada nasabah (pemesan) dengan harga jual senilai harga beli ditambah keuntungannya (margin) kemudian dalam hal ini bank harus memberitahu secara jujur harga pokok barang kepada nasabah berikut biaya yang diperlukan. Sehingga nasabah membayar harga barang yang telah disepakati tersebut pada jangka waktu tertentu yang telah disepakati. Penetapan harga jual di BMT UGT Sidogiri juga dilakukan dengan melihat prinsip-prinsip penetapan harga jual dalam Islam, yaitu saling ridha (antarrodin), tidak ada paksaan (ikroh), jujur, adil dan dilakukan negoisasi terlebih dahulu sebelum melakukan kesepakatan antara kedua belah pihak.

\section{KESIMPULAN}

Berdasarkan hasil analisis penelitian dan pembahasan, maka dapat diambil kesimpulan sebagai berikut:

a. Mekanisme penetapan harga yang digunakan di BMT UGT yaitu atas dasar negoisasi (tawar-menawar) yaitu dengan membentuk kesepakatan antara kedua belah pihak 
tanpa adanya unsur paksaan yang berpegangan dengan prinsip-prinsip syariah seperti saling ridho dan keadilan serta mempertimbangkan aspek-aspek lain seperti jangka waktu (tenor) pembiayaan, tujuan penggunaan dana serta kondisi keuangan anggota.

b. Penetapan harga akad murabahah di BMT UGT Capem Ketompen-Pajarakan berpatokan terhadap jumlah pengajuan pembiayaan dengan ketentuan margin antara $2 \%$ sd 2,5\%. Akan tetapi pada penentuan harga pembiayaan di BMT UGT dilakukan atas dasar negoisasi yang mana persentase margin dapat ditawar oleh anggota atas persetujuan komite atau kepala capem. Pembayaran angsuran dengan metode flat (metode penetapan harga rata-rata).

b. Kesesuaian penetapan harga jual pada pembiayaan murabahah di BMT UGT Capem Ketompen-Pajarakan Menurut tinjauan hukum perspektif Islam telah sesuai dengan tuntunan syariah, karena mengacu pada Fatwa DSN No. 04/DSN-MUI/IV/2000 tentang pembiayaan murabahah

\section{DAFTAR PUSTAKA}

IKAPI, Perbankan syari'ah ( Yogyakarta : Gadjah Mada University Press, 2009)

Kotler, Philip. Dasar-Dasar Pemasaran. (Jakarta : PT Indeks, 2007).

Kusmiyati, Asmi Nur Siwi. Risiko Akad dalam Pembiayaan Murabahah pada BMT di Yogyakarta (dari Teori ke Terapan) (Yogyakarta: La Riba, 2007).

Novita, Erna. Analisis Pengaruh Marketing Syari'ah terhadap Minat Anggota menggunakan produk murabahah Di BMT Hudatama Cabang Mangkang. ( Skripsi Program Ekonomi Islam IAIN Walisongo Semarang,2014).

Ulfi, Rahma Yanti. Analisis Faktor-Faktor yang Mempengaruhi Nasabah untuk Mendapatkan Pembiayaan Murabahah di BMT Al-hijrah Salo Kabupaten Kampar. (Skripsi Jurusan Ekonomi Islam Fakultas Syari'ah dan Hukum Universitas Islam Negeri Sultan Syarif Kasim Riau,Pekan Baru, 2015). 